\title{
Radiographic analysis of forensic dentistry
}

Thalita Queiroz Abreuª , Ana Emília Figueiredo de Oliveira ${ }^{\mathrm{a}}$, Elza Bernardes Ferreira ${ }^{\mathrm{b}}$, Mariana Figueiredo Lopes ${ }^{c}$, Maia Denise Regina Pontes Vieira ${ }^{\mathrm{b}}$

\begin{abstract}
Objective: Age estimation is an important element in the forensic investigation, being one of the data primary sources to establish the identity of living people or unknown mortal remains. The methods used for this purpose are those based on individuals' bones and teeth development. Since dental radiographs assume major role in the forensic context, this article aims to show, by means of literature review, the importance of dental radiographs as an aid in human identification process, particularly in the age estimation.

Conclusion: The forensic dental examination contributes significantly to human identification, no matter if it is a living, in advanced decay, skeletonized or charred body. Therefore, it is important to raise awareness among dental professionals about the need to properly record and archive the information and data obtained during the daily clinical routine, since the greatest support for identification in forensic dentistry, mainly the individual's age estimation, comes from clinical documentation produced daily by clinicians, especially dental radiographs.
\end{abstract}

Key words: Forensic dentistry, Panoramic radiography, Dental age determination, Bone age determination.

\section{Análise radiográfica em odontologia forense}

\section{RESUMO}

Objetivo: A estimativa da idade é um elemento importante na investigação pericial, sendo uma das fontes preliminares dos dados para estabelecer a identidade de pessoas vivas ou restos mortais desconhecidos. Os métodos mais utilizados para este fim são os baseados no desenvolvimento ósseo e dentário dos indivíduos. Uma vez que as radiografias odontológicas assumem papel de grande importância no contexto pericial, o presente trabalho tem como propósito evidenciar, por meio de revisão da literatura, a importância das radiografias odontológicas como subsídio no processo de identificação humana e em particular na estimativa da idade.

Conclusão: $O$ exame odontolegal contribui significativamente para a identificação humana, esteja o corpo vivo, em decomposição avançada, esqueletizado ou carbonizado. Para tanto, é importante a conscientização da classe odontológica da necessidade de se registrar e arquivar adequadamente as informações e dados obtidos durante a rotina clínica diária, uma vez que o maior suporte para a identificação em odontologia forense, principalmente a estimativa da idade do indivíduo, advém da documentação clínica produzida cotidianamente pelos clínicos, em especial as radiografias odontológicas

Palavras-chave: Odontologia legal, Radiografia panorâmica, Determinação da idade pelos dentes, Determinação da idade pelo isqueleto a Universidade Federal do Maranhão (UFMA), São Luiz, MA, Brazil.

${ }^{b}$ Universidade Aberta do SUS (UNA-SUS/UFMA) São Luiz, MA Brazil.

${ }^{c}$ Universidade CEUMA, São Luiz, MA, Brazil. 


\section{INTRODUCTION}

The Forensic Odontology or Forensic Dentistry is the science that relates Dentistry with the Law, especially in human identification. The definition of this specialty shows one of the main expertise areas of the dental surgeon operating in the expert function which is to determine the identity of an individual by examining dental characteristics in forensic dental identification [1,2].

The success in identifying a person's body brings considerable significance from the ethical, legal and criminal view. Human identification is not only a prerequisite to officially declare the death of individuals, but is also the basis for the investigation of crimes, mass disasters or war [3] crimes.

Historically, the application of radiology in forensic sciences was introduced in 1896, just one year after the discovery of X-rays by Roentgen, to demonstrate the presence of lead bullets inside a victim's head [4].

The oral cavity presents a great potential for the identification; the role played by the expert in forensic dentistry is extremely important since the examination of a body through the mouth and dental arches can be critical in a criminal forensics, being dental examination an option widely used. In addition, the dentist must be careful to keep the patients' medical records, radiographs and plaster models and must write down all the information because they may serve in the future for positive identification of victims [5].

In 1921, the possibility of using radiological imaging of the sinuses for identification purposes [6] arose. In 1927, it was reported the first complete radiological identification [7]. And in 1951 this technique was used in a work to identify bodies from a mass disaster [8].

Since then dental surgeons with special training and experience in Forensic Dentistry are often requested to assist in the identification of bodies, individual and mass disasters ones.

Among the various tests that the dental surgeon involved in expert function is able to perform the age estimation of individuals whose birth date is not proven is one of the most challenging. This challenge is close related to the fact that the expert must find biological parameters that enable to obtain the shortest time interval that encompass the person's actual or chronological age or body [9].

Since dental radiographs assumed major role in the forensic context, this paper aims to show, by means of literature review, the importance of dental radiographs as an aid in human identification process, particularly in age estimation.

\section{LITERATURE REVIEW}

The age estimation is an important element in the forensic investigation, being one of the primary data sources to establish the identity of living people or unknown mortal remains. The methods used for this purpose are those based upon individuals' bones and teeth development.
In 1992 was released a study that established the identity of edentulous individuals by comparing ante and postmortem maxillary occlusal radiographs. Twelve examiners with the following qualifications participated in the study: six radiologist dental surgeons, four dental surgeon specialists and two dental students. The study demonstrated that six out of the twelve observers were able to establish correctly the identity of all 20 cases examined. Among the specialists, five were radiologists and one was prosthetist. Other professionals got right between 3 and 8 identifications, while the two students missed two and four identifications, respectively [10].

In 2001 a work was undertaken to assess the value of dental radiographs for personal identification, in the absence of restorations. There were obtained 198 periapical and bitewing radiographs of teeth from 22 dry skulls. Each selected radiograph was evaluated by forensic odontologists, students and radiology technicians in attempt to correlate the radiographs with each skull. Success rates in the combination of radiographs ranged from 63,6 to $100 \%$. The average rate for forensic odontologists was $93.3 \%$, for students and technicians was $89.7 \%$ [11].

A case report published in 2006 was able to conclude that the expertise object aged 18 years or older. For this was used panoramic radiographic examination. For the author, the method of choice for an expert examination to age estimation is radiographic due to its practicality in obtaining data [9].

Some advantages of panoramic radiographic technique for forensic identification are: symmetry of the obtained images, overall view, simplicity to perform the procedure, exclusion of the oral cavity films, lower radiation dose and exposure time when compared to the full mouth intraoral radiographic examination [12].

In 2006, there was this forensic case where radiographs containing images with suitable quality for confrontation were used and enabled the identity determination of an individual who died in a car accident followed by the fire. With the correct processing and archiving of dental radiographs, clinicians were able to have in their custody documentation that allowed the proper monitoring of dental treatments performed and, eventually, subsidize information to the Justice [2].

In 2007 was published a report of an expert case where the identification of charred body was possible by using pre and post-operative radiographs of a bone fracture in the wrist joint. In these radiographs where found particularities of the plate and screws used in fracture reduction that were coincident with the necropsy findings. The authors emphasized that the filing of radiographs is essential to the forensic context because they can be ordered by the justice and used in the resolution of legal issues [13].

In 2007, two human cases of identification of charred bodies through dental and sinus radiographs were reported, highlighting the importance of documentation [14].

In the following year, there was another forensic case where the person's age of criminal responsibility was proven by age estimation expert examination. In order to 
do so, there levels of apical closure of third molars and the degree of epiphyseal closure of the radius and ulna were analyzed by means of panoramic and carpal radiographs, respectively [15].

In 2010, aiming to verify the applicability of dental age estimation method in a mixed population of Brazilians in the region of Baixada Cuiabana, State of Mato Grosso, Midwestern of Brazil, we analyzed 200 panoramic radiographs, being half of them from males and the other 100 from females, to check the percentage of correct responses in this sample using simple statistics. It was observed $54 \%$ correct answers in all subjects evaluated, the males radiographs obtained 55\% right and $45 \%$ wrong results, while the females ones showed $53 \%$ correct and 47\% wrong responses [16].

In an article published in 2013 was demonstrated the importance of expert examination to estimate age in living beings, presenting a case where the accused one claimed to be under 18 years old, with authentic civil registration proving his criminal responsibility age. According to the expert examination (qualified official document) the age of the accused was estimated to be less than 18 years old and therefore it was recognized the absence of culpability, presumption of absolute legal disability, which means that the person under 18 years does not have enough maturity to discern the consequences of his/hers actions [17].

In the year of 2014 there was an age estimation exam for civil registration purposes in the city of Porto Velho - Brazil, where several signs of illegal immigration attempted were detected and reported to inform the competent authorities. The author reports that the dental surgeon is often asked to help the judiciary when it needs to established someone's age by using forensic dentistry own scientific knowledge, and the expert should be aware of all the intricacies that surrounds this type of examination [18].

\section{DISCUSSION}

Forensic anthropology, through human identification, seeks to analyze, both in quality and in quantity, various types of characters that differ between individuals. Among these, one searches for the animal species, gender determination, age, skin color, height, biotype and particular signs [9]. Dental treatment results in unique qualities, individualizing people more and more. Most of the time, people are easily identified in routine radiographs in the dental clinic.

Concerning the applicability of dental radiographs within forensic dentistry, it is possible to find in literature many studies in which they were applied as a reference to compare the anatomy of the maxillofacial region.

Data showed in works published in 1992 and ratified in $2001[10,11]$ confirm and stress the relevance of more than one forensic specialist signing the identification form of the individual who went through the forensic examination. Searches also show that forensic examiners that are welltrained in the subject of radiology are capable of determining positively the identity, even in cases where the teeth are missing.
That being said, one could say that the comparison between radiographic images has some limitations, despite its advantages, because many times it is a subjective examination, which depends a great deal on how experienced the forensic professional is. In addition to that, the radiographic image can vary significantly depending on the incidence of the $\mathrm{x}$-ray beam.

Despite the benefits of using panoramic radiography within forensic dentistry [12], the use of this type of radiography in the legal area has shown some flaws in the realization of the post-mortem panoramic, especially concerning the cost of the equipment and the positioning of the body. Another issue lies on the fact that many devices are previously adjusted so that the peak kilo-voltage is at a very low level to compensate the lack of tissue in a skull sample.

There is a consensus in literature about how the technique in forensic dental identification requires suitable material to accomplish the comparison of information and how dental radiographs contain relevant features to the process of people individualization. In order to demonstrate the importance of these pieces as source of information for human identification it is essential the correct archiving of tests $[2,13]$.

There are several methods to estimate age and they are presented by various scientific groups. Each of them ends up using their own methodological protocol and different procedures to evaluate their method. This leads to severe limitations in the comparison, reproduction and verification of these methods. Through a study published in 2010, it was possible to observe the need for adjustments of the methods or for the creation of a specific applicability method to individuals of that Brazilian region [16].

Thus, the ideal is to use national or regional research data so the study variables are similar to those that focus on the development of the individual that will go under forensic examination [15].

Furthermore, there are divergences in teeth mineralization stages, especially when comparing populations with different racial characteristics, since the development of individuals is influenced by genetic, climatic, socioeconomic, environmental, hormonal and nutritional factors.

Since young people of the same age may present different degrees of maturity there is a need to use different parameters for age evaluation in forensic dentistry.

According to Lisbôa [16], among the studies for tooth development evaluation, the most cited are Nolla [17], Nicodemo et al. [18] and Demirjian et al. [19]. Starting from the age of 14, one can notice a significant increase in the number of errors when comparing the chronological age with the method developed by Nicodemo [13]. This is probably due to the decrease in the number of teeth in stage of mineralization within individuals above this age, in other words, individuals who are able to be analyzed by this method.

The estimate of age in children or young people normally provides the obtaining of shorter gaps, because the individual is going through a progressive development. The gaps 
become longer as the person reaches adult age (stabilization phase), which makes the estimate more complex, as the analysis of the regressive factors is required [15].

On the other hand, data from a 2010 study were applied to both national and international charts, resulting in the obtaining of an age gap that enabled the establishment of police procedure, based on technical and scientific criteria [15].

Human identification by comparison through radiographs within forensic dentistry is a technique that is intended mainly to provide the identification of corpses in different stages of putrefaction, skeletonization or carbonization, and also, when only remains, mortal or not, are available. In these situations, different radiographic techniques can be utilized: periapical, interproximal, panoramic, carpal and sinuses $[9,11,14]$.

With these examinations, it becomes possible to create estimates of age based on technical-scientific criteria, which can be an appropriate foundation for the establishment of police procedure, which enables the verification and application of the suitable punishment to the accused.

\section{CONCLUSION}

The forensic dental examination gives a significant contribution to the human identification, whether the body is alive, in advanced state of decomposition, skeletonized or carbonized.

In order to do so, it is important that the dental community acknowledges the necessity of properly registering and filing the information and data obtained during the clinical daily routine. After all, the biggest foundation for the identification within forensic dentistry, mainly the estimate of the individual's age, comes from the clinical documentation generated daily by the clinical professionals, especially the dental radiographs.

\section{REFERENCES}

1. Moreira, R.P.; Freitas, A.Z.V.M. Dicionário de Odontologia Legal. Rio de Janeiro: Guanabara Koogan. 1999.

2. Silva RF, Pereira SDR, Mendes SDSC, Marinho DEA, Júnior ED. Radiografias odontológicas: Fonte de informação para a identificação humana. Odontologia. Clín. Científ. 2006;5(3):239-42

3. Schmeling A, Geserik G, Reisinger W, Olze A. Age estimation. Forensic Sci Int. 2007;165:178-81. https://doi.org/10.1016/j.forsciint.2006.05.016

4. Eckert WG, Garland N. The history of the forensic applications in radiology Am J Forensic Med Pathol.1984;5:53-6. https://doi.org/10.1097/00000433198403000-00010
5. Coutinho CGV, Ferreira CA, Queiroz LR, Gomes LO, Silva UA. O papel do Odontolegista nas perícias criminais. Rev Fac Odontol. 2013;18(2)

6. Gruber J, Kameyama MM. O papel da radiologia em odontologia legal. Pesqui Odontol Bras. 2001;15(3):263-8. https://doi.org/10.1590/S151774912001000300014

7. Culbert WL, Law FM. Identification by comparison of roentgenograms of nasal accessory sinuses and mas- toid processes. J Am Med Assoc. 1927;88:1634. https://doi.org/10.1001/jama.1927.02680470020009

8. Singleton $\mathrm{AC}$. The roentgenological identification of victims of the "Noronic" disaster. Am J Roentgenol. 1951;66(3):375-84.

9. Cornélio Neto WL, Cornélio GC, Conceição MB. Estimativa da idade pelos 3 o molares através de rx: relato de caso. RGO. 2006;54(3):230-3.

10. Borrman $\mathrm{H}$, Grondahl HG. Accuracy in establishing identity in edentulous individuals by means of intraoral radiographs. J Forensic Odontostomatol. 1992;10(1):1-6.

11. Sholl AS, Moody GH. Evaluation $f$ radiographic identification: an experimental study. Forensic Science International. 2001;115:265-269. https://doi.org/10.1016/S0379-0738(00)00305-4

12. Oliveira MMN, Correia MF, Barata JS. Aspectos relacionados ao emprego da radiografia panorâmica em pacientes infantis. Rev Fac Porto Alegre. 2006;47:15-9.

13. Silva RF, Pinto RN, Mendes SDSC, Marinho DEAM, Teixeira EA. Importância pericial das radiografias da articulação do punho para a identificação humana. Rev Imagem. 2007;29(1):165-7.

14. Campobasso CP, Dell'Erba AS, Belviso M, Di Vella G. Craniofacial identification by comparison of antemortem and postmortem radiographs: two case reports dealing with burnt bodies. Am J Forensic Med Pathol 2007;28(2):182-6. https://doi.org/10.1097/PAF.0b013e31806195cb

15. Silva RF, Marinho DEA, Botelho TL, Caria PHF, Bérzin F, Daruge Júnior E. Estimativa da idade por meio de análise radiográfica dos dentes e da articulação do punho: relato de caso pericial. Arquivos em Odontologia. 2008;44(2).

16. Lisbôa MB. Radiografia Panorâmica no Contexto da Segurança Pública: Estimativa da Idade no Caso de Belém/PA [dissertação]. São Paulo: Universidade Federal do Pará; 2013.

17. Nolla, C. M. The development of permanent teeth. J Dent Child. 1960; 27(4):254-66

18. Nicodemo RA, Moraes LC, Médici Filho, E. Tabela cronológica da mineralização dos dentes permanentes entre brasileiros. Rev Fac Odont (São José dos Campos). 1974;3(1):55-6,

19. Demirjian A, Goldstein H, Tanner JM. A new system of dental age assessment. Human Biology. 1973;45:211-27.

20. Oliveira FT. Estimativa da idade cronológica por meio de avaliação radiográfica da mineralização de terceiros molares e altura do ramo da mandíbula [tese]. Bauru: Faculdade de Odontologia de Bauru, da Universidade de São Paulo; 2010.

21. Silva RF, Solon DSC, Mendes SDSC, Rosário Júnior AF, Dias PEM, Leandro $B$, et al. Evidência documental $X$ evidência biológica para estimativa da idade - relato de caso pericial. Rev Odontol Bras Central. 2013 21(60).

22. Sousa JR. Laureano Filho JR. Porto LVMG. Ramos RP. Real MF. Real FS Imigração transfronteiriça revelada durante exame de estimativa de idade - relato de caso, 2014. Disponível em: http://www. derechoycambiosocial. com/revista035/Imigracao transfronteirica.pdf [Acesso em: 22 abr. 2014]

23. Mincer $\mathrm{HH}$, Chaudhry J, Blankenship JA, Tur Ner EW. Postmortem dental radiography. J Forensic Sci. 2008;56(2):405-7. https://doi.org/10.1111/ j.1556-4029.2007.00645.x 